\section{Malynka 0., Perevozova I.}

\title{
COMPARISON OF LATERAL VS. VERTICAL MARKETING CONCEPTS IN BRAND CREATION PROCESS
}

Об’єктом дослідження є латеральний маркетинг. Це нова концепція маркетингу, яка дозволяє розширити інструментарій маркетингу за рамки послідовного та логічного процесу, на якому він базується, i допомогти компаніям генерувати нові ідеї, які не можуть запропонувати ні споживачі, ні маркетингові дослідження. В ході дослідження використовувалися традиційні методи дедукиї та індукції, науковоі класифікачії та групування, а також емпіричні методи для порівняння концепчій латерального і вертикального маркетингу та обговорення їхньої ролі в процесі створення брендів. Виявлено, що латеральний маркетинг не знаходиться вище вертикального - вони доповнюють одне одного. Більше того, латеральний маркетинг не може існувати без вертикального, адже рано чи пізно у новій ринковій категорії теж з'являються конкуренти, з якими треба знову ж-таки боротися, щоб не втратити лідируючих позицій. Проте це - два різні підходи, які мають багато особливостей та відмінностей. При застосуванні концепцї вертикального маркетингу усі інновацї будуть створюватися всередині фіксованого ринкового простору. Це пов'язано з тим, що такі новинки позитивно впливають на рівень продажів, адже з'являються нові потенційні покупці. Проте дані інноваційні стратегї̈ не створюють нових категорій та ринків. I в підсумку рівень продажів за умов надто великої сегментацї зростає дуже незначно. Тому такий підхід до створення продуктів дуже часто не може дати очікуваних результатів. Автори рекомендують за таких умов застосовувати латеральний маркетинг, адже це найефективніший спосіб конкурениї на «зрілих» ринках, де мікросегментація і перенасичення брендами не залишає місчя для нових можливостей. Принципи прийняття рішень у латеральному маркетингу дуже відрізняються. Тут працює творче та інтуіттвне мислення. Потрібно розвивати креативність у працівників компанї, долучати до відділів маркетингу неординарних особистостей.

Ключові слова: бренд-менеджмент, вертикальний маркетинг, латеральний маркетинг, нові ринки, нові продукти, товарна політика.

\section{Introduction}

When applying the concept of vertical marketing, all innovations will be created within a fixed market space. This is due to the fact that such new products have a positive effect on the level of sales, as there are new potential buyers [1-3]. However, these innovative strategies do not create new categories and markets. And as a result, the level of sales in the case of too large segmentation increases insignificantly. Therefore, such an approach to product creation very often can not give the expected results. And under these conditions usage lateral marketing is relevant, as it is the most effective way of competition in the «mature» markets, where micro-segmentation and overbranding do not leave room for new opportunities [4-6]. Principles of decision making in lateral marketing are very different. Creative and intuitive thinking works here. So, the object of research is lateral marketing. It is a new marketing concept that allows expanding marketing tools beyond the consistent and logical process of marketing and helps companies to generate new ideas, which neither consumers, nor marketing research could offer - that's why lateral marketing concept is so important in brand creation process. And the aim of research is comparison of vertical and lateral marketing concepts and to discuss their role in brand creation process.

\section{Methods of research}

For the research let's use traditional methods: - methods of deduction and induction for specific observations and broader generalizations of vertical and lateral marketing theories;

- scientific classification and grouping for the definition of product innovations categories;

- empirical methods for comparing the concepts of lateral and vertical marketing and discussing their role in the process of creating brands.

\section{Research results}

What can the «traditional» marketing department offer while creating new products? Product innovations, of course. Usually everything is done correctly, sticking to academic marketing rules - the potential consumers' wants and needs are researched, and the target market is determined, this concept to be vertical marketing [1]. However, all the innovations will be created within a fixed market space. Product innovations of this type are usually divided into the following categories [2, 3]:

- Changing the product's main characteristics through expanding or narrowing. (Example, juices: low sugar, more fruits, «fresh», with vitamins, no supplements etc.). 
- Changing the size. (Example, potato chips: packages of 35, 50, 100, 200 grams, multipacks etc.).

- Changing the package. (Example, milka chocolate is sold in chocolate tiles, gift boxes, iron souvenir packages, but the chocolate itself is of the same taste).

- Changing the design, but the container, package, and size remain unchanged. (Example, skis: many manufacturers just change the color and design of some new models).

- Supplements, adding an ingredient to the main product. (Example, cookies with cinnamon, white chocolate, black chocolate, jam, sugar powder etc.).

- Decreasing consumer efforts. (Example, some supermarkets and nightclubs create special free routes for the convenience of their clients)

No doubt, these innovations have positive influence on the sales, because they attract new potential buyers. However, such innovative strategies don't create new categories and markets. As a result, sales on the markets with excess segmentation increase insignificantly. Thus, very often this approach to product innovations doesn't provide expected results.

In this case it is recommended to use lateral marketing, because it is the most effective way of competing on the «mature» markets, where micro-segmentation and plenty of brands don't leave any space for the new opportunities [7].

Lateral marketing doesn't stand higher than the vertical one - they complete each other. Moreover, lateral marketing cannot exist without the vertical one, because sooner or later, new competitors appear in the new market category, and a company should fight again, in order not to lose the leading position. However, these two different approaches have many peculiarities and differences $[8,9]$.

What happens when vertical marketing is used? As it has been already mentioned above, target market is determined, and product innovations are created. Vertical marketing process is based on logic - the company has marketing department with certain marketing tools, which creates products. When the market is not mature, this approach works perfectly. New positioning and differentiation points are found, and potential consumers turn to become real. But in the long run, on the mature markets these new products provide very insignificant increase in sales, and sometimes products of the same category «destroy» each other.

Lateral marketing works in a different way. It is based on finding new opportunities through appealing to one or several consumers' wants which were ignored in the previous identification of a product or service. It is clear that the product itself needs to be changed [5].

The principles of decision-making in lateral marketing are very different. Creative and intuitive thinking is of utmost importance here. It is necessary to develop the creativity of the company's employees, to involve extraordinary personalities in marketing departments. For this reason, creative agencies are very popular. The logic doesn't surprise a consumer anymore - necessity in totally unexpected decisions which reject any sequence of thoughts.

But it shouldn't forget that many new products are not accepted by the market. And, of course, brand new products are more difficult to be sold - it takes some time for the potential consumers to understand their value before they would like to buy them. Therefore, lateral products are riskier than the traditional ones. But if such innovations are accepted by the market, their sales exceed the sales of a new product which is created within the existing category.

Differences between vertical and lateral marketing are presented in the Table 1. So, now the advantages and disadvantages of lateral marketing are clear. However, the theory itself is not so important as the set of tools which helps to apply this concept correctly. In work [6] this methodology is described, describing the process of creating a side product.

Table 1

Differences between vertical and lateral marketing $[6,10]$

\begin{tabular}{|c|c|c|}
\hline Specifics & Vertical marketing & Lateral marketing \\
\hline $\begin{array}{l}\text { Is based } \\
\text { on }\end{array}$ & $\begin{array}{l}\text { - Wants, needs, wishes, } \\
\text { people, situations and ways } \\
\text { of using the product. } \\
\text { - Our mission, innovations, } \\
\text { considering what kind of } \\
\text { a company we want to be }\end{array}$ & $\begin{array}{l}\text { - Ignored wants, needs, wishes, } \\
\text { people, situations and ways of using } \\
\text { the product. } \\
\text { - Openness for a new mission } \\
\text { (when needed). } \\
\text { - Innovations that originate beyond } \\
\text { the existing proposition }\end{array}$ \\
\hline Functions & $\begin{array}{l}\text { - Within marketing process. } \\
\text { - Vertically }\end{array}$ & $\begin{array}{l}\text { - Beyond the logic of marketing } \\
\text { process. } \\
\text { - Laterally }\end{array}$ \\
\hline Allows & $\begin{array}{l}\text { - At the early stage of mar- } \\
\text { ket development. } \\
\text { - To develop markets. } \\
\text { - To convert potential con- } \\
\text { sumers into the real ones. } \\
\text { - At the late stage of market } \\
\text { development. } \\
\text { - Low sales growth, but } \\
\text { easy to sell new products }\end{array}$ & $\begin{array}{l}\text { - At the early stage of market } \\
\text { development. } \\
\text { - To create markets, categories. } \\
\text { - To cover target consumers/si- } \\
\text { tuations which are not covered with } \\
\text { existing products. } \\
\text { - At the late stage of market de- } \\
\text { velopment. } \\
\text { - High growth and higher risks }\end{array}$ \\
\hline $\begin{array}{l}\text { Source } \\
\text { of the } \\
\text { demand }\end{array}$ & $\begin{array}{l}\text { - Market share of the com- } \\
\text { petitors. } \\
\text { - Converting potential con- } \\
\text { sumers into the real ones }\end{array}$ & $\begin{array}{l}\text { - Can provide growth on its own, } \\
\text { without influence on other markets. } \\
\text { - Deprive many other categories of } \\
\text { the market share of homogeneous } \\
\text { competitive products }\end{array}$ \\
\hline Is used & $\begin{array}{l}\text { - At the early stage of the } \\
\text { life cycle of a market or } \\
\text { a product. } \\
\text { - For the low-risk strategy. } \\
\text { - With limited resources. } \\
\text { - To protect the market } \\
\text { through its fragmentation }\end{array}$ & $\begin{array}{l}\text { - At the maturity stage of the life } \\
\text { cycle of a market or a product. } \\
\text { - For the high-risk strategy. } \\
\text { - With available resources. } \\
\text { - To attack markets with substitute } \\
\text { goods }\end{array}$ \\
\hline $\begin{array}{l}\text { Responsi- } \\
\text { bility }\end{array}$ & Marketing departments & $\begin{array}{l}\text { Marketing departments are not al- } \\
\text { ways responsible for the creation } \\
\text { of markets. Often the responsibility } \\
\text { lies on: } \\
\text { - creative agencies; } \\
\text { - entrepreneur; } \\
\text { - small and medium companies; } \\
\text { - technical, scientific and research } \\
\text { departments }\end{array}$ \\
\hline
\end{tabular}

At the first glance it may seem that the search for non-standard solutions, as well as creativity in general, is a chaotic process. But if lateral marketing is a process, it means that it can be organized. Even creativity may have its own methods. For example, Mozart, da Vinci, Edison had their creative methods.

In the late 90's was suggested similar method - the «lateral thinking» method - a process which helps overcome stereotypes and look at the problem from the other side. In order to find a non-standard way out of the situation, it is necessary to reject the sequence of thoughts 
and logic, because of frames and limitations. These frames make obstacles for the new ideas [3].

In its nature, lateral thinking is creative and intuitive. It is the way which rejects the sequence of thoughts and leads to the creation of brand new products.

The process of creating any lateral product can be divided into several universal sub-processes [11]:

1) concentrating on the object;

2) determining the gap in the characteristic;

3) establishing communication (new idea and concept). Any ideas and solutions can be logically connected. But at the beginning there was no gap in logic, and therefore it is necessary to stimulate non-standard thoughts at the stage of the rupture, to unite the incompatible. It is important to set the stimuli clearly, so new ideas and products will appear.

\section{Conclusions}

So, it is found that lateral marketing is not above the vertical - they complement each other. Moreover, lateral marketing can not exist without vertical, because sooner or later, in the new market category, too, there is competitors, with whom it is necessary again fight, in order not to lose the leading position. However, these are two different approaches that have many peculiarities and differences. If under the ideal conditions lateral thinking spreads throughout the company as an approach which generates ideas and solves problems, then in real life this occurs only in those companies which are considered to be really innovative. Those who approve of new ideas from their employees, allocate funds for finding non-standard solutions and can mobilize and retain talented people. Speaking of innovations, it isn't possible to limit the concept just with the creation of lateral products.

\section{References}

1. Kotler P. Marketing Management-Analysis, Planning, Implementation, and Control. Upper Saddle River: Prentice Hall, 1994. 704 p.

2. Abrams B., Garino D. Package Design Gains Stature as Visual Competition Grows // Wall Street Journal. 1981. P. 25.

3. McCarthy E., Perreault W. Essentials of Marketing. E. McCarthy and Associates Inc., 1994. 258 p.

4. Borkazovska L. V. Application of lateral marketing in the innovation activity of enterprises-manufacturers of commercial equipment // Economic sciences. Series: Economics and Management. 2014. Vol. 11. P. 44-52.

5. Keller K. L. Branding and Brand Equity. Cambridge: Marketing Science Institute, 2002. 86 p.

6. Pride W., Ferrell W. Marketing: Concepts and Strategies. Boston: Houghton Mifflin Company, 1991. 198 p.

7. Kotler P., Trías De Bes F. Lateral Marketing: New Techniques for Finding Breakthrough Ideas. Hoboken: John Wiley \& Sons, Inc., 2003. 206 p.

8. Mariotti John L. Smart Things to Know About Brands \& Branding. Capstone Pub, 2001. 180 p.

9. Gordon R. Phantom Products // Forbes. 1984. P. 202-204.

10. Pomirko N. M. Lateral marketing as an effective means of leading a company in a highly competitive market // Bulletin of the Khmelnitsky National University. 2011. Vol. 3, Issue 5. P. $106-109$.

11. Srull T. K. Methodological Techniques for the Study of Person Memory and Social Cognition // Handbook of Social Cognition. Vol. 2. Hillsdale: Lawrence Erlbaum, 1984. P. 1-72.

Malynka Oksana, PhD, Associate Professor, Department of Entrepreneurship and Marketing, Ivano-Frankinsk National Technical University of Oil and Gas, Ukraine, ORCID: http://orcid.org/00000002-6259-7020, e-mail: ok.framboise@gmail.com

Perevozova Iryna, Doctor of Economic Sciences, Professor, Department of Entrepreneurship and Marketing, Ivano-Frankinsk National Technical University of Oil and Gas, Ukraine, ORCID: http://orcid.org/ 0000-0002-3878-802X, e-mail: perevozova@ukr.net 